\title{
The development of environment-based picture storybooks to increase the fourth grade students' reading interest
}

\author{
Alpiyah $^{1^{*}}$ \\ Alben Ambarita ${ }^{2}$ \\ Pargito $^{3}$ \\ ${ }^{1,2,3}$ Postgraduate Program, University of Lampung, Bandar Lampung, Indonesia
}

\begin{abstract}
This study aims to produce an environment-based picture storybook to increase the reading interest of fourth-grade elementary school students and obtain the results of book product testing until the suitable book used as reading learning for elementary school students is obtained. This research is development research which consists of three stages, which include (1) Preliminary Study, (2) Product Development, (3) Product Test. The subjects of this study were fourth-grade students of SDN 1 Rajabasa Raya, Rajabasa Sub District, Bandar Lampung City, Lampung Province. The data analysis technique in this study adopted a qualitative descriptive technique. Data collection was carried out using questionnaires and interviews. The product validity was tested by learning material and learning media experts. Based on the research conducted, it was found that: (1) environmentalbased picture storybooks can increase students' reading interest; (2) environmental-based picture storybooks are suitable to be used as learning resources in learning to read for elementary school students. The results of this study found that the level of validity of the development of picture storybook learning media products in increasing reading interest in fourth-grade elementary school students was very good.
\end{abstract}

\section{KEYWORDS}

Picture books, environment, students' reading interest

Received: 2 August 2021

Accepted: 14 August 2021

Published: 16 August 2021

\section{Introduction}

Books are one of the learning media used to train children's interest in reading. Books are a source of intelligence for human life (Sumitra \& Sumini, 2016). Books do not always contain information that is printed in writing and lines but can also be illustrated so that it can be used as an alternative in the learning process. An example of a book, in this case, is a picture storybook that will attract the attention of students in learning. It has been proven that stories are very liked by students or adults, especially when accompanied by pictures that make reading material not monotonous. Picture storybooks also have several advantages, including helping the emotional development of students, making them feel happy and knowing about the world, and can stimulate students' imaginations (Suryaningsih \& Fatmawati, 2017; Davis (1997) explained that a book containing illustrated stories may become an interesting educational medium to encourage the students' learning spirit and is easily found in newspapers and bookstores, containing stories about daily life, and provides various learning styles.

It can be concluded that picture storybooks can attract the attention of students to learn since this storybook contains not only reading paragraphs but also accompanied by pictures. Picture storybooks can be used to help stimulate and enrich the imagination of children. In addition, Mitchell in Burhan Nurgiantoro said that a picture storybook is a book that displays pictures and text where the two are interrelated. Pictures alone are not enough to tell a story without text. Therefore, the combination of pictures and text in picture storybooks will complement each other. Lukens in Burhan Nurgintoro confirms that picture and written illustrations are two different media. However, both of them in the picture storybook will together form a single unit.

In addition, literacy learning is also important to emphasize to students. This is because the literacy or reading and writing skills of children in Indonesia are still relatively low. This has been proven by the results of the PIRLS 
(Progress In International Reading Literacy Study) research in 2006 as it showed that the average reading comprehension ability of elementary school students in Indonesia scored 405. This value was still below the average score of 500 and was ranked 41 out of 45 countries (Mullis, Martin, Kennedy, \& Fo, 2007). These findings indicate that literacy skills carried out in schools have not been as successful as expected. Therefore, early literacy is an important factor to be developed in elementary schools so that the behavior and life skills expected in society can be formed. Seorang pendidik dalam hal ini harus mampu meningkatkan minat siswa dalam membaca. Interest is a feeling in the form of a preference and a sense of interest in an activity or activity that is indicated by the desire or tendency to pay attention to the activity without the need for someone else to order it to be done with awareness and followed by a sense of pleasure. Interest in reading is a motivational construct that has been described as a personal investment or a relatively stable evaluative orientation toward a certain domain (Guthrie et al,2007,p. 285). Having an interest in reading is a very good investment. Reading is an essential factor from all aspects. It makes students want to learn more. Good achievement will be achieved when there is students' desire to read with good reading interest. Interest in reading in this case can be improved through appropriate teaching methods. One of these methods is by using picture storybooks.

Interest in reading will emerge and become part of the self because of the efforts of oneself where environmental factors are the supporting factors. The importance of environmental education is for a sustainable living so that environmental education must be applied in the community from an early age (Ichwan, 2018). The environment is a system that is a unitary space with all objects, power, circumstances, and living things, including humans and their behavior that affects the continuity of life and the welfare of humans and other living things (Manik, 2018). From the above definition, it is clear that living things, especially humans, are those who always take advantage of their environment, which includes respiration, meeting food needs, housing, and others. Therefore, humans need the environment to meet their daily needs. Humans as living beings who excel in their ecosystems have the power to react and consume natural resources for their needs. The pictures contained in picture storybooks serve to illustrate the characterizations, settings, and events that are used to build the plot of a story. The combination of color gradations can provide illustrative power in a picture storybook (Hidayah, 2019) Environmental education in the school environment is the basic capital for the formation of environmental ethics in future generations (Mulyana, 2019).

The condition found based on learning observations in grade IV Elementary School in Rajabasa Sub District is that student learning is still not encouraging. The cause of the lack of success in learning, especially in elementary schools, which is the most dominant at this time is the low level of student interest in reading. Findings from interviews conducted with teachers indicate that the cause of the not optimal learning is the unattractiveness of textbooks as a reference in reading. This research was conducted based on previous research that examined the development of illustrated children's storybooks with the insertion of local Balinese culture on reading interest and attitudes of fifth-grade elementary school students, curriculum 2013, conducted by I Md. Aditya Dharma. Other previous research in this regard is research on the development of environmental-based picture storybooks as a learning resource to improve the learning outcomes of fourth-grade elementary school students by Tias Anggraini. Based on these reasons, relevant research and literature studies were carried out.

\section{Research method}

The type of this research is Research and Development (R\&D). Sukmadinata (2016) reveals that research that has a process of developing new products or developing existing and accountable products is the meaning of Research and Development (R\&D). This study aims to increase students' interest in reading through the use of picture storybook learning media that will be produced in a product. Sukmadinata (2016) suggests that the research and development steps consist of three stages, namely: (1) Preliminary Study, (2) Product Development, (3) Product Test. (1) The stages in the Preliminary Study consist of a literature study, a field survey, and the preparation of an initial product draft. (2) In product development, the stage is the preparation of a draft at the beginning of the development which is carried out by referring to the needs analysis and literature study. (3) The product test is carried out with a limited trial. The data analysis technique used in this study was descriptive which was used to determine the feasibility of the picture storybook media.

The effectiveness of the media used in this study is known by using descriptive and percentage testing techniques as follows: Percentage = Total Score x 100\% Total maximum score The percentages obtained can be categorized into categories in the following table:

Table 1. The category of data analysis results

\begin{tabular}{cc}
\hline & Interval category \\
\hline $\mathbf{8 1 - 1 0 0 \%}$ & Very High \\
\hline $\mathbf{6 1 - 8 1 \%}$ & High
\end{tabular}




\begin{tabular}{rc}
\hline $41-60 \%$ & Sufficient \\
\hline $21-40 \%$ & Low \\
\hline $0-20 \%$ & Very Low \\
\hline
\end{tabular}

The validation results are said to be feasible to be tested if the minimum percentage is more than or equal to 61\% (Mawardi (2014)

\section{Results and discussion}

The data collection technique in this study was carried out through the preliminary study stage. These three stages consist of literature study, field survey, and preparation of the Sukmadinata's product draft (2016). A literature study is research to study concepts related to products or models. The research that will be studied is the concept of increasing interest in reading elementary school students in grade IV in the form of picture storybooks which will later be developed based on the lesson material. The field survey in this study was carried out to collect data related to the school's need for picture storybooks and the implementation of learning in schools, especially those related to the reading interest of students in grade IV. At the field survey stage at SDN 1 Rajabasa Raya in Bandar Lampung City, the aim was to find out the school's need for picture storybooks in fourth grade. This is done by using material assessment data on Theme 9, "The Richness of My Country", in Sub-theme 1 Lesson 1 "Wealth of Energy Resources in Indonesia". Based on the data obtained from the field survey, the researchers compiled an initial list of product models to be developed and compiled a picture storybook following the theory. The initial design, in this case, determines the learning materials and sketches before finally establishing the software and the review process that will be carried out by media experts and material experts. The development in this study was carried out through validation tests from material experts and validation tests from media experts.

The results of the validation test and several research results, one of which found that picture storybooks were very feasible to be used in learning activities. Research conducted by (Risma et al, 2020) states that picture storybook media is very feasible to be used in learning activities. This is evident from the results of the material expert test obtained by $87.5 \%$ and media experts by $96 \%$. This opinion is in line with Mawardi's opinion (2018) which states that learning media are everything that can be used as a means of distributing messages and information on learning materials so that the process becomes fun. Several studies have also revealed that picture storybooks are very useful in helping learning activities, especially in improving students' reading skills

The conclusion that can be drawn based on the results of the validation test and some of the results of these studies, is that picture storybooks are very feasible to be used in learning activities.

\section{Conclusion}

Based on the analysis of teacher needs that has been carried out, the learning carried out has not used book teaching materials that were compiled and developed by the teacher themselves, but only books published from publishers with unattractive content which in the end makes students bored. Therefore development of picture story book is required to improve students' reading interest. Development of picture story book environmental based is one of strategies that can be used to solve the problem of students' low reading interest.

\section{References}

Davis, R. S., (1997). Komik: Pengajaran multidimensi di kelas keterampilan terpadu. Jepang: Universitas Nagoyama.

Guthrie., Hoa., Wigfield., Tonks., Humenick., \& Littles. (2004). Reading motivation and reading comprehension growth in the later elementary years. 32(3).

Ichwan, muhammad munirul. (2018). Pengaruh dukungan keluarga dan peraturan sekolah terhadap karakter siswa kelas IX MTSN 6 Ponorogo Tahun Ajaran 2017/2018. Skripsi: Institut Agama Islam Negeri (IAIN) Ponorogo.

Hidayah, Nurul. (2019). Pembelajaran bahasa dan sastra indonesia untuk SD. Yogyakarta: Penerbit Pustaka Pranala.

Manik. (2018). Pengelolaan lingkungan hidup. Jakarta: Putra Grafika.

Mawardi. (2014). Model desain pembelajaran konsep dasar PKN berbasis belajar mandiri menggunakan moodle. Salatiga: Widya Sari Press Salatiga.

Mullis, I.,Martin.,Kennedy, A., \& Foy P. (2007). Progress in international reading literacy study. Pirls 2006 report. In: Lynch School of Education, Boston College, Chestnut Hill, MA: TIMMS \& PIRLS International Study Centre. International Association for the Evaluation of Educational Achievement (IEA).

Mulyana, Rachmat. (2019). Penanaman etika lingkungan melalui sekolah perduli dan berbudaya lingkungan. Jurnal Tadris Unimed. 6(2).

Solfiah, Yeni., Risma, Devi., Hukmi., \& Kurnia, Rita. (2020). Pengaruh buku cerita bergambar terhadap pengetahuan manajemen bencana anak. Jurnal Obsesi : Jurnal Pendidikan Anak Usia Dini. 5(1), 783-794.

Sukmadinata. (2016). Metode penelitian pendidikan. Bandung: PT Remaja Rosdakarya.

Suryaningsih, Eni., \& Fatmawati, Laila. (2017). Pengembangan buku cerita bergambar tentang mitigasi bencana erupsi gunung api untuk siswa SD. Jurnal Profesi Pendidikan Dasar. 4(2).

Sumitra, Agus., \& Sumini,, Nita. (2019). Peran guru dalam mengembangkan kemampuan minat baca anak usia dini melalui metode read read aloud. Jurnal Ilmiah Potensia. 4(2), 115-120. 